\title{
THIOL/DISULPHIDE HOMEOSTASIS, ISCHEMIA MODIFIED ALBUMIN, AND FERROXIDASE AS OXIDATIVE STRESS MARKERS IN WOMEN WITH OBESITY WITH INSULIN RESISTANCE
}

\section{TIOL-DISULFIDNA HOMEOSTAZA, ISHEMIJSKI MODIFIKOVANI ALBUMIN I FEROKSIDAZA KAO MARKERI OKSIDATIVNOG STRESA KOD GOJAZNIH ŽENA SA INSULINSKOM REZISTENCIJOM}

\author{
Elif Ates ${ }^{1}$, Turan Set ${ }^{1}$, Süleyman Caner Karahan ${ }^{2}$, Cemile Biçer $^{3}$, Özcan Erel ${ }^{3}$ \\ ${ }^{1}$ Department of Family Medicine, Faculty of Medicine, Karadeniz Technical University, Trabzon, Turkey \\ ${ }^{2}$ Department of Biochemistry, Faculty of Medicine, Karadeniz Technical University, Trabzon, Turkey \\ ${ }^{3}$ Department of Biochemistry, Faculty of Medicine, Yıldırım Beyazıt University, Ankara, Turkey
}

\section{Summary}

Background: The purpose of the study was to determine oxidative stress-related plasma thiol/disulphide, ischemiamodified albumin (IMA) levels and ferroxidase activity among women with obesity in insulin-resistant and noninsulin-resistant groups in comparison with an overweight group.

Methods: We compared plasma thiol/disulphide, IMA levels, and ferroxidase activity between the study groups. We analyzed plasma thiol/disulphide homeostasis with a newly developed automated measurement method; IMA with Albumin Cobalt Binding Test and ferroxidase (ceruloplasmin) levels with an automated, colourimetric method.

Results: There were no significant differences between insulin-resistant and non-insulin-resistant women with obesity in terms of plasma native thiol, total thiol, disulphide, disulphide/native thiol ratio, disulphide/total thiol or native thiol/total thiol values. Ferroxidase activity was higher in insulin-resistant than in non-insulin-resistant women with obesity and higher in the total women with obesity group than in the overweight subjects $(p<0.001$, and $p=0.014$, respectively). IMA was lower in the insulin-resistant group than in the non-insulin-resistant group and overweight groups ( $p=0.011$, and $p=0.042$, respectively).

\section{Kratak sadržaj}

Uvod: Svrha ove studije bila je da se odredi nivo oksidativnog stresa vezan za plazma tiol/disulfid, nivo ishemijski modifikovanog albumina (IMA) i aktivnost feroksidaze kod gojaznih žena iz insulinski rezistentne i nerezistentne grupe u poređenju sa grupom žena sa prekomernom težinom. Metode: Uporedili smo plazma tiol/disulfid, nivoe IMA i aktivnost feroksidaze među ispitivanim grupama. Analizirali smo plazma tiol/disulfidnu homeostazu pomoću novorazvijene automatizovane metode merenja, IMA testom vezivanja albumin kobalta, a feroksidazu (ceruloplazmin) automatizovanom kolorimetrijskom metodom.

Rezultati: Nije bilo značajnih razlika između insulinski rezistentnih i nerezistentnih žena i gojaznih žena u smislu vrednosti koje se odnose na prirodni tiol, ukupni tiol, disulfid, odnos disulfid/prirodni tiol, disulfid/ukupni tiol ili prirodni tiol/ukupni tiol. Aktivnost feroksidaze bila je viša kod žena rezistentnih na insulin nego kod gojaznih žena koje nisu insulinski rezistentne, a veća je u ukupnom broju gojaznih nego kod ispitanica sa prekomernom težinom ( $p$ $<0,001$ i $p=0,014$, po ispitivanju). IMA je bio niži $u$ grupi koja je rezistentna na insulin nego u grupama koje nisu rezistentne na insulin i grupi sa prekomernom težinom $(p=0,011$ i $p=0,042)$.

Address for correspondence:

Elif Ates

Karadeniz Technical University, Faculty of Medicine

No 6 Department of Family Medicine C Blok

61080 Trabzon, Turkey

Cell phone: +90 5325840772

Telephone: +90462 3775469

e-mail:drealtunbas@yahoo.com 
Conclusions: The significantly greater increase in ferroxidase activity in insulin-resistant subjects with obesity may reflect its role as a positive acute phase protein. These findings may be related to the pathogenesis of the disease. Changes in oxidative status occur in women with obesity, and partially in overweight subjects. The ferroxidase activity of ceruloplasmin plays a crucial role in iron homeostasis and lowers oxidative stress by reducing the detrimental effects of iron.

Keywords: biomarkers, ceruloplasmin, insulin resistance, obesity, oxidative stress, thiols

\section{Introduction}

Obesity is a multifactorial and complex disease resulting from the interaction of genetic and environmental factors and is an important and priority health problem worldwide. Obesity is a chronic disease as well as a risk factor for the development of cardiovascular diseases, insulin resistance, diabetes, non-alcoholic fatty liver disease and cancer $(1,2)$. Depending on the pathogenesis of obesity, lipid oxidation is impaired, and a protein uncoupling oxidative phosphorylation in white fat cells is dysfunctional in these individuals (1).

Insulin signalling can be altered by the concentration of reactive oxygen species (ROS) being enhanced by moderate concentrations and suppressed by persistent exposure to ROS. High ROS levels can be seen in diabetic patients, and decreased insulin reactivity can be ameliorated by antioxidants, such as $\mathrm{N}$-acetylcysteine (NAC). Albumin is the main plasma protein and plays various roles. It has antioxidant properties and is the major source of thiol in plasma. Thiol levels may be related to obesity, with low levels capable of facilitating the development of the disease (3).

The oxidant-antioxidant balance is necessary in order to sustain optimal physiological conditions in organisms. Thiol redox protects organisms against oxidative reactions. Disulphide bridges located between two cysteine amino acids regulate the oxidation of proteins (4). An increase in thiol levels or thiol/disulphide ratios has been attributed to antioxidant protection $(5,6)$. During oxidative stress, disulphide formation occurs between protein thiol groups and low-molecular-mass thiols. Dynamic thiol-disulphide homeostasis can be maintained by reducing the disulphide bonds that form to thiol groups. This homeostasis is necessary for antioxidant protection, regulation of enzymatic activity, and detoxification. It is also implicated in the pathogenesis of a variety of diseases, such as diabetes, cardiovascular diseases and cancer. Determination of dynamic thiol/disulphide homeostasis can, therefore, provide valuable information concerning various normal or abnormal biochemical processes (7). Persistent exposure to oxidative stress leads to systemic abnormalities, such
Zaključak: Značajno veće povećanje aktivnosti feroksidaze kod gojaznih subjekata otpornih na insulin može odražavati njegovu ulogu kao pozitivnog proteina akutne faze. Ovi nalazi mogu biti povezani sa patogenezom bolesti. Promene u oksidativnom statusu javljaju se kod gojaznih žena i delimično kod ispitanica sa prekomernom težinom. Feroksidazna aktivnost ceruloplazmina igra ključnu ulogu u homeostazi gvožđa i smanjuje oksidativni stres smanjenjem štetnih efekata grožđa.

Ključne reči: biomarkeri, ceruloplazmin, insulinska rezistencija, gojaznost, oksidativni stres, tioli

as autoimmunity, cardiovascular dysfunction, carcinogenesis, diabetes mellitus, obesity, neurodegeneration and ageing $(8,9)$.

Dynamic thiol/disulphide homeostasis may be detected in many diseases. In most, antioxidants such as native thiols and total thiols decrease, while oxidants such as disulphide increase in patient groups compared to controls (10-13).

Oxidative stress biomarkers in body fluids and tissues can be used in the diagnosis, treatment and follow-up of diseases in both research and the clinical setting (10-15). There are numerous oxidative-stress related biomarkers, but one of the most commonly used parameters is ischemia-modified albumin (IMA). This is a novel marker of ischemia generated due to hypo-oxygenation and increased hydroxyl free radicals (14). This ischemia marker also rises under conditions of oxidative stress. Some studies have shown high IMA levels in populations with obesity $(15,16)$.

Ceruloplasmin, another plasma protein, exhibits ferroxidase activity. Ferroxidase exhibits antioxidantlike activities. It has been suggested that it functions in copper transport and some oxidation reactions, and is also implicated in radical scavenging and other antioxidant processes (17). The role of ceruloplasmin in the regulation of iron homeostasis is well established, but the significance of its other activities is less clear.

Research is continuing into serological biomarkers with high validity and reliability, and which are preferably minimally invasive. These will facilitate the work of clinicians in the diagnosis, treatment and follow-up of obesity.

The purpose of this study was to determine the antioxidant activities of plasma proteins such as thiol/disulphide levels, ferroxidase activity, and ischemia modified albumin, as oxidative stress markers in subjects with obesity with and without insulin resistance compared to an overweight group. To the best of our knowledge, this is the first report in the literature concerning these markers in insulin resistance in women with obesity. 


\section{Materials and Methods}

\section{Patients group}

This cross-sectional study was performed between November 2016 and July 2017 at the University Family Medicine Outpatient Clinic. Randomly selected women admitted to our outpatient clinic for weight loss were enrolled. We excluded patients with diabetes, hypertension, cardiovascular, respiratory and metabolic disorders, and those using long-term medication or antioxidant food supplements other than as symptomatic treatment for any reason.

\section{Methods}

Participants' descriptive characteristics were investigated; age, height, weight, and waist-hip ratio measurements were determined. Patients with body mass index (BMI) values of 30 or more were considered individuals with obesity. The HOMA-IR method [fasting insulin $(\mathrm{mU} / \mathrm{L}) \times$ fasting plasma glucose $(\mathrm{mmol} / \mathrm{L}) / 405)]$ was used to identify insulin resistance, and values above 2.7 were considered as insulin-resistant.

The participants were divided into three groups, insulin-resistant, non-insulin-resistant women with obesity, and overweight women. We compared their plasma native thiol, total thiol, disulphide, disulphide/thiol, ferroxidase, and IMA levels. After complete clotting, venous blood samples were centrifuged at $3500 \mathrm{rpm}$ for $5 \mathrm{~min}$. Then these were transferred to Eppendorf tubes and stored at -80$\} \mathrm{C}$ until analysis. All chemicals were purchased from Sigma-Aldrich Chemical Co. (Milwaukee, WI) and Merck Co. (Darmstadt, Germany). A Cobas C 501 automated clinical chemistry analyzer (Roche Diagnostics $\mathrm{GmbH}$, Mannheim, Germany) was used for analysis.

Plasma thiol/disulphide homeostasis, a newly developed automated measurement method, was originally studied by Erel \& Neselioglu (7). The total and native thiol measurement ran parallel in two vessels. The native thiol (R-SH) content of the sample is measured using modified Ellman reagent by 5,5 dithiobis-2-nitrobenzoic acid (DTNB) in one vessel. In another one, disulphide bonds (-S-S-) in the sample were reduced to free thiol groups by sodium borohydride ( $\mathrm{NaBH} 4)$. After removing unused reductant remnants by formaldehyde, total thiol (R-SH) concentration was measured. The half value of the difference between total thiol and native thiol amounts gave the disulphide bond amount. Pooled human serum was used as a control material and 2mercaptoethanol solution was used as calibrator. Results were expressed as $\mu \mathrm{mol} / \mathrm{L}$.

Ferroxidase (ceruloplasmin) levels were measured using the automated, colourimetric method described by Erel (18). This method is based on the enzymatic oxidation of ferrous ion to ferric ion. Serum samples were incubated at $37^{\circ} \mathrm{C}$ with ferrous ion $\left(\mathrm{Fe}^{2+}\right)$ in $0.45 \mathrm{~mol} / \mathrm{L}$ acetate buffer ( $\mathrm{pH}$ 5.8). The chromogen, 3-(2-pyridyl)-5,6- bis (2-[5-furylsulfonic acid])-1,2,4triazine, formed a coloured complex with the remaining non-oxidized ferrous ions and measured photometrically at 590-610 $\mathrm{nm}$. The difference in the ferrous ion concentration before and after the enzymatic reaction indicated the amount of oxidized ferrous ion. The amount of enzyme activity which converted $1 \mathrm{mmol}$ of the substrate into product per minute was defined as one unit. The results were expressed as units per litre of serum. Deionized water was used as the first calibrator, and EDTA solution was the second calibrator. Pooled human serum was used as a control.

For measurement of IMA levels, the Albumin Cobalt Binding Test was used. This involved the addition of $50 \mathrm{~mL} 0.1 \%$ cobalt (II) chloride $\left(\mathrm{CoClv}, 6 \mathrm{H}_{2} \mathrm{O}\right)$ to the patient serum. After mixing, followed by 10-min incubation for albumin cobalt binding, $50 \mathrm{~mL} 1.5$ $\mathrm{mg} / \mathrm{mL}$ dithiothreitol was added. After mixing followed by $2 \mathrm{~min}$ of incubation, $1.0 \mathrm{~mL}$ of $0.9 \%$ sodium chloride solution was added in order to reduce the binding capacity. Blanks were prepared in a similar manner, but using distilled water instead of dithiothreitol. The absorbance of samples was measured at $470 \mathrm{~nm}$ using a spectrophotometer. The results were expressed as absorbance units (ABSUs) (19).

After measurement of plasma native thiol, total thiol, disulphide, ferroxidase, ischemia-modified albumin levels, determinations of plasma index 1, index 2 and index 3 levels in all three groups were done.

Index 1 was defined as the plasma disulphide/ native thiol ratio, index 2 as the disulphide/total thiol ratio, and index 3 as the native thiol/total thiol ratio.

\section{Statistical analysis}

Data analysis was performed on SPSS Version 18 software. Normal distribution of numeric variables was evaluated by the Kolmogorov-Smirnov test. We analyzed descriptive statistics and presented them as mean \pm standard deviation. We evaluated the results using the independent samples t-test, One-Way ANOVA and the Pearson correlation test. Statistical significance was set at $\mathrm{p}<0.05$.

\section{Ethical approval}

This study was preapproved by the University local ethical committee. Written consent was sought and obtained from all participants prior to the study (2016/134 - 13.10.2016). 


\section{Results}

Group 1 consisted of 30 insulin-resistant women with obesity, Group 2 of 31 non-insulin-resistant women with obesity, and Group 3 of 34 overweight women. The groups' mean age, BMI and HOMA-IR values are shown in Table $I$.

Primary and secondary outcome measures and comparisons thereof are shown in Table II. Significant differences were determined between the groups in terms of ferroxidase and IMA (Table II).
A positive correlation was determined between BMI and ferroxidase levels $(r=0.464, p<0.001)$ and between waist-hip ratio and ferroxidase levels $(r=0.471, p<0.001$, Figure 1).

No correlation was determined between BMI, HOMA-IR, and waist-hip ratio and IMA, native thiol, total thiol, disulphide, index 1 , index 2 or index 3 ( $p>0.05)$.

Table I Comparison of age, BMI, HOMA-IR and waist-hip ratio according to groups.

\begin{tabular}{|l|c|c|c|c|}
\hline & Group 1 & Group 2 & Group 3 & p-value \\
\hline Age (years) & $29.93 \pm 10.04$ & $38.29 \pm 10.85$ & $32.94 \pm 12.09$ & $0.014^{\mathrm{a}}$ \\
\hline BMI $\left(\mathrm{kg} / \mathrm{m}^{2}\right)$ & $37.39 \pm 5.92$ & $35.11 \pm 4.83$ & $25.69 \pm 3.61$ & $<0.001^{\mathrm{b}}$ \\
\hline HOMA-IR & $5.42 \pm 3.93$ & $1.74 \pm 0.64$ & $1.46 \pm 0.73$ & $<0.001^{\mathrm{c}}$ \\
\hline Waist-hip ratio & $0.90 \pm 0.06$ & $0.90 \pm 0.07$ & $0.81 \pm 0.06$ & $<0.001^{\text {da }}$ \\
\hline
\end{tabular}

Significant difference between groups 1 and $2(p=0.011), b$ significant difference between groups 1 and 3 and between groups 2 and $3(<0.001){ }^{C}$ significant difference between groups 1 and 2 and between groups 1 and $3(<0.001)$, ${ }^{d}$ significant difference between groups 1 and 3 and between groups 2 and 3 (<0.001). All parameters are presented as mean \pm standard deviation.

Table II Comparison of the oxidative stress marker and index results' between the groups.

\begin{tabular}{|c|c|c|c|c|}
\hline & Group 1 & Group 2 & Group 3 & p-value \\
\hline Native thiol $(\mu \mathrm{mol} / \mathrm{L})$ & $412.29 \pm 51.15$ & $494.11 \pm 43.64$ & $408.07 \pm 43.44$ & 0.273 \\
\hline Total thiol $(\mu \mathrm{mol} / \mathrm{L})$ & $444.91 \pm 52.08$ & $431.91 \pm 48.54$ & $444.87 \pm 48.57$ & 0.494 \\
\hline Disulphide $(\mu \mathrm{mol} / \mathrm{L})$ & $16.36 \pm 9.18$ & $19.38 \pm 8.23$ & $18.39 \pm 8.81$ & 0.393 \\
\hline Index 1 & $4.08 \pm 2.47$ & $4.96 \pm 2.18$ & $4.53 \pm 2.21$ & 0.324 \\
\hline Index 2 & $3.68 \pm 2.05$ & $4.44 \pm 1.82$ & $4.08 \pm 1.85$ & 0.299 \\
\hline Index 3 & $92.66 \pm 4.16$ & $91.10 \pm 3.64$ & $91.83 \pm 3.71$ & 0.289 \\
\hline Ferroxidase $(\mathrm{U} / \mathrm{L})$ & $571.43 \pm 150.20$ & $515.16 \pm 111.06$ & $430.38 \pm 89.86$ & $<0.001^{\mathrm{a}}$ \\
\hline IMA (ABSU) & $0.70 \pm 0.11$ & $0.78 \pm 0.12$ & $0.77 \pm 0.10$ & $0.009^{\mathrm{b}}$ \\
\hline
\end{tabular}

a Significant difference between groups 1 and 3 and between groups 2 and $3\left(p<0.001\right.$ and $p=0.014$, respectively), $b_{\text {significant }}$ difference between groups 1 and 2 and between groups 1 and 3 ( $p=0.011$ and $p=0.042$, respectively). All parameters are presented as mean \pm standard deviation.
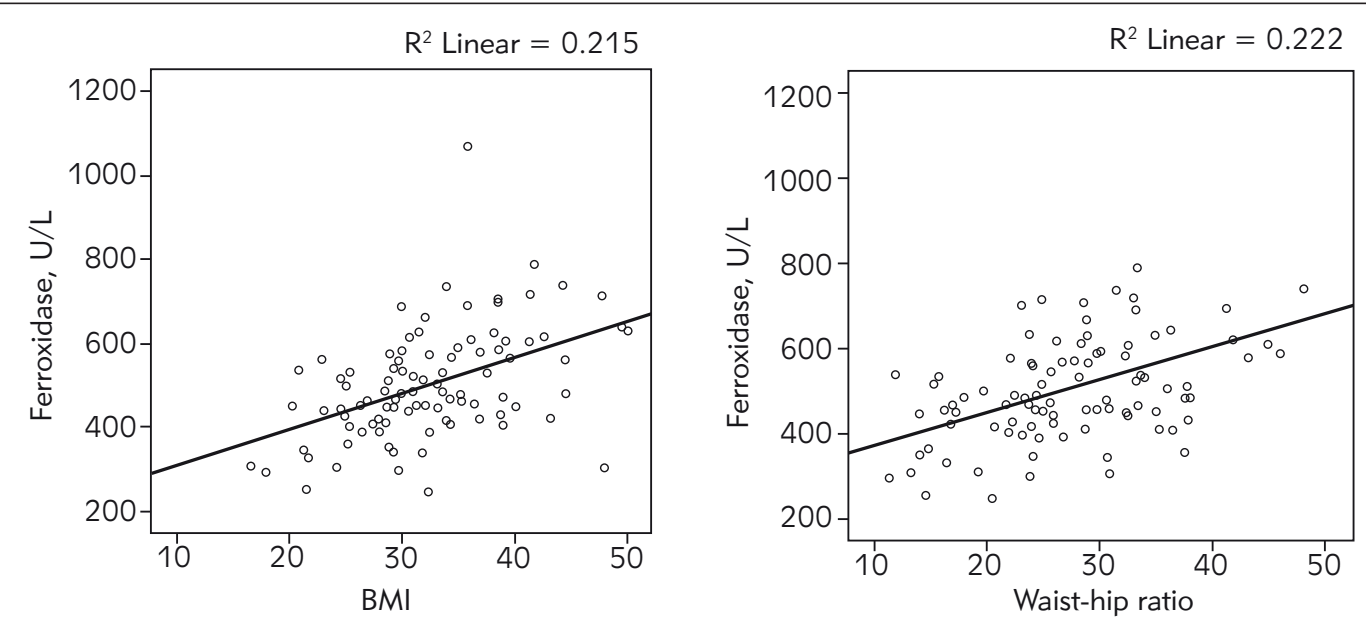

Figure 1 Correlations between BMI, waist-hip ratio and ferroxidase levels. 


\section{Discussion}

Obesity is an inflammatory illness causing an increase in oxidative stress (20). An increase in antioxidants may be expected when the balance shifts towards increased oxidative stress. Our findings indicated no difference in terms of thiol-disulphide hemostasis between insulin-resistant and non-insulinresistant patients with obesity. Ferroxidase levels were significantly higher in the insulin-resistant women with obesity than in the overweight group. In terms of insulin resistance, the only parameter in which a significant difference was observed was IMA, levels of which were lower in the insulin-resistant group than in the non-insulin-resistant group. The only parameter that can be used as an indicator for insulin resistance, within the parameters studied in our research, is IMA.

We determined no significant differences in native and total thiol and disulphide levels between the groups. One study of patients with polycystic ovary syndrome (PCOS) reported higher serum thiols and lower disulphide levels in PCOS subjects with obesity than in the controls with obesity (5). We also observed the same effects, although the differences were not significant. In a study of attention deficithyperactivity disorder, patients' mean serum native and total thiol levels were higher than those of the controls (21). In a study evaluating thiol-disulphide homeostasis in acute brucellosis, the authors observed lower native and total thiol levels in an acute brucellosis group than in a healthy group. They also reported higher index 1 and 2 and lower index 3 ratios than in the healthy controls (11). Another study involving adolescent patients with PCOS reported significantly lower native and total thiol levels in overweight + PCOS adolescents compared to both normal weight patients with PCOS and to control adolescents (22). In another study, significant differences were determined between acute myocardial ischemia patients and control subjects in terms of native thiol, total thiol, and disulphide levels, as well as disulphide/native thiol and disulphide/total thiol ratios (12). However, no significant difference was determined between insulin-resistant and non-insulinresistant patients with obesity in terms of native and total thiol, or disulphide levels in our study.

Ozler et al. (23) reported increased disulphide/ native thiol and disulphide/total thiol ratios, while native thiol/total thiol decreased in the cord blood of babies born to a mother with obesity or diabetes mellitus, and associated these rates with adverse outcomes in gestational diabetes mellitus. In another study, while disulphide/native thiol and disulphide/ total thiol ratios were elevated, the native thiol/total thiol ratio decreased in a group with chronic central serous chorioretinopathy group compared to healthy individuals (13). We observed no significant difference between our study groups in terms of plasma disulphide/native thiol, disulphide/total thiol or native thiol/total thiol values. Overweight and obesity caused similar changes in thiol/disulphide homeostasis.

Significantly, we determined a higher level of ferroxidase in the insulin-resistant women with obesity group than in the overweight group. In a study comparing acute brucellosis and control patients, higher ceruloplasmin levels were observed in patients with acute brucellosis than in the control group (11). Our results are consistent with the previous literature. Ceruloplasmin, a positive acute-phase reactant, takes part in the immune system response. Additionally, it plays a protective role against oxygen radicals. Ceruloplasmin is the major plasma protein with ferroxidase activity. It is also referred to as ferroxidaseI or EC 1.16.3.1. On the other hand, in contrast to cytosolic ferritin, serum ferritin is relatively iron-poor and may contain only a few atoms of iron. Its $\mathrm{H}$ chain ferroxidase activity is important for intracellular storage and release of iron in a controlled manner. So we focused on ceruloplasmin protein for evaluation of ferroxidase activity in blood.

Interestingly, there are papers which show that even in the low plasma ceruloplasmin levels, there might not be ferroxidase activity in blood. That means; the presence of ceruloplasmin concentrations in blood does not always indicate it functions properly (24). So the measurement of ceruloplasmin activity seems more valuable than the measurement of its level regarding the function of the protein.

Previous studies have shown that serum albumin, which exhibits anti-inflammatory and antioxidant characteristics, is associated with insulin resistance. They have concluded albumin may have a protective effect against incident diabetes (25). Levels of the modified form of albumin were low in the insulin-resistant group in our study. In terms of insulin resistance, the only parameter that differed significantly was IMA, levels of which were lower in the insulin-resistant group than the non-insulinresistant group. Piva et al. (15) reported an increase in IMA combined with lower levels of nitrate/nitrite (NOx) in people with obesity, and determined a negative correlation between $\mathrm{BMI}$ and $\mathrm{NOx}$ as an oxidative biomarker, suggesting a possible interplay with oxidative stress in obesity.

One study of children with obesity reported a positive correlation between oxidant parameters such as disulphide/native thiol and disulphide/total thiol ratios and $\mathrm{BMI}$, and a negative correlation between antioxidant parameters such as native thiol, total thiol, and native thiol/total thiol ratios and $\mathrm{BMI}(26)$. We observed no correlation between BMI, HOMA-IR, or waist-hip ratio, and IMA, native thiol, total thiol, disulphide, index 1, index 2 and index 3 . However, a positive correlation was determined between $\mathrm{BMI}$ and ferroxidase levels, between waist-hip ratio and ferroxidase levels, and between IMA and native thiol, and total thiol. 
The main limitation of our study was the sample size, which may limit the applicability of the results to the general population.

This is the first study to investigate thioldisulphide hemostasis in patients with obesity and insulin resistance. It is also the only study to concurrently investigate all variables, such as plasma native thiol, total thiol, disulphide, disulphide/native thiol, disulphide/total thiol and native thiol/total thiol, ferroxidase and IMA.

\section{Conclusion}

Obesity and insulin resistance are common health problems. The balance between oxidative stress and antioxidant defence is disturbed in these cases. All parameters discuss here were plasma proteins or their structural, functional units which were affected and in different ways function as an antioxidant during oxidative stress. For example; higher ferroxidase activity of ceruloplasmin in insulin-

\section{References}

1. Gurevich-Panigrahi T, Panigrahi S, Wiechec E, Los M. Obesity: pathophysiology and clinical management. Curr Med Chem 2009; 16: 506-21.

2. Perović Blagojević I, Ignjatović S, Macut Dj, KoturStevuljević J, Božić-Antić I, Vekić J, Bjekić-Macut J, Kastratović-Kotlica B, Andrić Z, llić D. Evaluation of a summary score for dyslipidemia, oxidative stress and inflammation (the doi score) in women with polycystic ovary syndrome and its relationship with obesity. J Med Biochem 2018; 37: 476-85.

3. Hildebrandt W, Hamann A, Krakowski-Roosen H, Kinscherf R, Dugi K, Sauer R, et al. Effect of thiol antioxidant on body fat and insulin reactivity. J Mol Med 2004; 82: 336-44.

4. Go YM, Jones DP. Thiol/disulphide redox states in signaling and sensing. Crit Rev Biochem Mol 2013; 48: 173-91.

5. Yildirim M, Turkyilmaz E, Neselioglu S, Alisik M, Avsar AF. Dynamic Thiol-Disulphide Status in Polycystic Ovary Syndrome and Its Association with the Pathogenesis of the Disease. Gynecol Obstet Invest 2017; 82: 54-9.

6. Ninić A, Bogavac-Stanojević N, Sopić M, Munjas J, Kotur-Stevuljević J, Miljković M, Gojković T, KalimanovskaOštrić D, Spasojević-Kalimanovska V. Superoxide dismutase isoenzymes gene expression in peripheral blood mononuclear cells in patients with coronary artery disease J Med Biochem 2019; 38; 284-91.

7. Collinson P. Laboratory medicine is faced with the evolution of medical practice. J Med Biochem 2017; 36: 211-5. resistant subjects may indicate that the body tries to eliminate the production of toxic iron products by converting ferrous iron to ferric iron, which allows iron binding to transferrin protein. In this study, we showed that plasma proteins have important roles in antioxidant defence against obesity-related problems and disturbance of their functions may result in more aggressive progress of clinical conditions of these patients.

Acknowledgements. Our study was previously presented as an oral presentation by us at the $17^{\text {th }}$ International Eastern Mediterranean Family Medicine Congress in Adana, Turkey, in 2018.

\section{Conflict of interest statement}

The author reports neither conflicts of interest nor any competing financial interests in this work. This investigation did not receive any financial support from outside companies or institutions, and the authors have no conflicts of interest.

8. Chen Y-I, Wei P-C, Hsu J-L, Su F-Y, Lee W-H. NPGPx (GPx7): a novel oxidative stress sensor/transmitter with multiple roles in redox homeostasis. Am J Transl Res 2016; 8: 1626.

9. Alvarez JA, Chowdhury R, Jones DP, Martin GS, Brigham $\mathrm{KL}$, Binongo JN, et al. Vitamin D status is independently associated with plasma glutathione and cysteine thiol/ disulphide redox status in adults. Clin Endocrinol 2014; 81: 458-66.

10. Dogru A, Balkarli A, Cetin GY, Neselioglu S, Erel O, Tunc SE, et al. Thiol/disulphide homeostasis in patients with ankylosing spondylitis. Bosn J Basic Med Sci 2016; 16: 187.

11. Kolgelier S, Ergin M, Demir LS, Inkaya AC, Aktug Demir $N$, Alisik M, et al. Impaired Thiol-Disulphide Balance in Acute Brucellosis. Jpn J Infect Dis 2017; 70: 258-62.

12. Kundi $H$, Ates I, Kiziltunc $E$, Cetin $M$, Cicekcioglu $H$, Neselioglu S, et al. A novel oxidative stress marker in acute myocardial infarction; thiol/disulphide homeostasis. Am J Emerg Med 2015; 33: 1567-71.

13. Turkoglu EB, Dikci S, Çelik E, Erel Ö, Neselioglu S, Alı ık $M$, et al. Thiol/disulphide homeostasis in patients with central serous chorioretinopathy. Cur Eye Res 2016; 41: 1489-91.

14. Gursoy AY, Caglar GS, Demirtas S. Ischemia modified albumin in perinatology. Eur J Obstet and Gynecol Reprod Biol 2017; 210: 182-8.

15. Piva SJ, Tatsch E, De Carvalho JAM, Bochi GV, Kober H, Duarte $T$, et al. Assessment of inflammatory and oxidative biomarkers in obesity and their associations with body mass index. Inflammation 2013; 36: 226-31. 
16. Mehmetoğlu I, Kurban S, Yerlikaya FH, Polat H. Obesity is an independent determinant of ischemia-modified albumin. Obes Facts 2012; 5: 700-9.

17. Puhalo Sladoje D, Kisić B, Mirić D. The monitoring of protein markers of Inflammation and serum lipid concentration in obese subjects with metabolic syndrome. J Med Biochem 17; 36: 366-74.

18. Erel O. Automated measurement of serum ferroxidase activity. Clin Chem 1998; 44: 2313-9.

19. Bar-Or D, Lau E, Winkler JV. A novel assay for cobaltalbumin binding and its potential as a marker for myocardial ischemia-a preliminary report. J Emerg Med 2000; 19: 311-5.

20. Dandona P, Aljada A, Bandyopadhyay A. Inflammation: the link between insulin resistance, obesity and diabetes. Trends Immunol 2004; 25: 4-7.

21. Avcil S, Uysal P, Avcil M, Alışık M, Biçer C. Dynamic thiol/disulphide homeostasis in children with attention deficit hyperactivity disorder and its relation with disease subtypes. Compr Psychiatry 2017; 73: 53-60.

22. Ozler S, Oztas E, Tokmak A, Ergin M, Isci E, Eren F, et al. The association of thiol/disulphide homeostasis and lipid accumulation index with cardiovascular risk factors in overweight adolescents with polycystic ovary syndrome. Clin Endocrinol 2016; 84: 516-23.

23. Ozler S, Oztas E, Erel O, Guler BG, Ergin M, Uygur D, et al. Impact of Gestational Diabetes Mellitus and Maternal Obesity on Cord Blood Dynamic Thiol/Disulphide Homeostasis. Fetal Pediatr Pathol 2017; 36: 8-15.

24. Takeuchi Y, Yoshikawa M, Tsujino T, Kohno S, Tsukamoto $N$, Shiroi A, et al. A case of aceruloplasminaemia: abnormal serum ceruloplasmin protein without ferroxidase activity. Journal of Neurology, Neurosurgery \& Psychiatry, 2002; 72: 543-5.

25. Baldane S, Kendir Cl, Kirac CO, Ipekci S, Tekin G, Unlu A, Kebapcilar L. Effects of glucose ingestion on serum fractalkine levels in healthy subjects and newly diagnosed type 2 diabetic patients. J Med Biochem 2018; 37: 3738.

26. Elmas $B$, Karacan $M$, Dervişoğlu $P$, Kösecik $M$, Şgüven $P$, Bal C. Dynamic thiol/disulphide homeostasis as a novel indicator of oxidative stress in obese children and its relationship with inflammatory-cardiovascular markers. Anatol J Cardiol 2017; 18: 361. 